\title{
Blossom beetle (Meligethes aeneus Fab.) as a yield factor in turnip rape (Brassica campestris $\mathbf{L}$.)
}

\author{
UNTO TULISALO \\ Öljynpuristamo Oy, SF-00810 HELSINKI, Finland \\ TUOMO WUORI \\ Ritokalliontie 11 C, SF-00330 HELSINKI, Finland
}

\begin{abstract}
Over the period from 1972-1982 the incidence of blossom beetles and their effect on yield formation in rape were studied in field trials and cage experiments at the Agricultural Research Centre, Vantaa, near Helsinki. The beetles migrated to the winter rape stands in May, when maximum daily temperatures rose above $+15^{\circ} \mathrm{C}$, and the migration to the spring rape stands occurred about three weeks later. The population peak in both winter and spring rapes occurred just before flowering.

During the 1970's the diminishing cultivation of winter turnip rape, the chief host of the blossom beetle, together with an increase in the extent of spring rapes resulted in the reduction of beetle populations to such low levels that intensive control measures were not required until 1981. It appears that the blossom beetles are gradually adapting themselves to the developmental rhytm of spring turnip rape.

In the cage experiments beetles were maintained on the plants a) from the seedling stage to flowering, b) from flowering to maturity and c) from the seedling stage to maturity, starting with populations of 5,15 or 25 beetles/plant. In the first treatment the beetles had no significant effect upon yields, as the plants were able to compensate for the injuries. In the other treatments even the lowest population density reduced yields. The larvae, too, contributed to the yield loss. Apparently a vigorous stand can tolerate large numbers of beetles up to a few days before flowering, provided they are promptly destroyed after that.

In the field trials, yield losses caused by natural populations of beetles ranged from $0-34$ $\%$. Even lower incidences than 2 beetles/plant caused measurable losses in yield. The injured plants produced fewer siliquas than the control plants, but tended to compensate by increasing seed number and seed weight.

The trial results confirm that the threshold level, 1 beetle/plant at the early bud stage, should be followed. On the other hand they clearly demonstrate that the threshold level is essentially dependent upon the growing conditions and time of injury. For fully effective control generally two applications of insecticide are needed. The best control strategy in the future will probably involve a comprehensive regional application eg. in two to three year sequences in order to prevent the beetle populations from building up to excessive levels.
\end{abstract}

Index words: Blossom beetles, rapeseed, threshold levels for control, yield 


\section{Introduction}

The biossom beetle (Meligethes aeneus) is a permanent pest throughout the entire cultivation area of rapeseed in Europe. The damage caused by blossom beetles to rapeseed is a very complicated question and no simple numerical data can be given to quantify it. The response of oilseed rape to pests is influenced greatly by a complex of several environmental factors: water consumption, nitrogen nutrition, temperature etc. (WINFIELD 1961, PALLUT et al. 1984). In addition, the ability of the rape plant to compensate for injuries plays a key role in yield formation (WINFIELD 1961, Williams \& Free 1979, McGregor 1981). The effect of minor factors depends on the optimum balance among the major factors.

Seed yield per rape plant is determined by the number of pods, seeds per pod and seed weight. Of these components the number of pods per plant has the greatest impact on yield (Olsson 1960) and thus the blossom beetle has a direct effect on yield by reducing the number of flower initials. Recent studies with spring rape have shown, however, that of the flowers that open only $45 \%$ develop into pods (TAYO \& MORGAN 1975). Therefore provided the damage occurs early in the flowering stage, rape plants can possibly lose a proportion of their flowers without loss of seed yield (Mendham \& Scott 1975). The capacity for compensating for such losses by retention of flowers varies under different growing conditions.

Since the nineteenth century considerable research has been carried out on blossom beetles. As early as 1854 HeEger described them as pests. A few years later Gallus (1866) gave a good description of the biology of this group and of the injuries they cause. Among others Wolf \& KRAUSE (1925) disputed the blossom beetle's status as a pest and KALT (1918) even regarded Meligethes as a beneficial insect. Later studies, however, explored the biology of the blossom beetle more thoroughly (BURKHARDT \& LENGERKEN 1920, NoLTE 1954, FrizsChe 1957, BlazeJEVSKa 1960).
After the first controversial studies by FABER et al. (1920) the agronomic importance of Meligethes aeneus as a permanent pest of cruciferous plants was clarified and by the end of the 1940's its status as a pest was well accepted, when the acreage of various forms of oilseed rape began to increase greatly. Many detailed aspects of its life cycle have been studied since then, e.g. natural enemies (OSBORN 1960), temperature and humidity preferences (Nolte 1959), overwintering (Nolte 1954), colour vision (NolTE 1959) and host plants (PrúfFer 1958).

The chemical control of the blossom beetle is well documented in the literature. However, studies on the abundance of M. aeneus and its effect on the yield of the host plant or economic threshold levels of control are not so numerous. As well as describing injuries (cf. MAurer \& Menche 1940), Winfield (1961) has studied control measures for Trowse mustard (Brassica juncea) and Gould (1975) for winter and spring rape (B. napus). It was not until the 1970's that FrEE and Williams (1978, 1979 a) investigated in considerable depth the yield losses caused by blossom beetles in Trowse mustard and spring rape. The ability of rape plants to compensate for pest damage is well illustrated in their studies.

In Finland the blossom beetle is a common insect throughout the country (VAPPULA 1962). It has been known as a pest of swede, turnip and cabbage since 1897 (REUTER 1898). The beetle has also been found to injure flowering sprouts of cauliflower and broccoli (VAPPULA 1962). It became a really harmful pest during the 1950's and 1960's as the cultivation of winter turnip rape became prevalent. After the gradual introduction of spring oilseed brassicas - a little rape but mainly turnip rape - the mean annual number of beetles decreased right up till 1977. It was not until 1981 that the beetles started once again to cause significant losses in several areas.

The aim of the present study was to assess the effect of Meligethes aeneus on rapeseed 
yields in field trials and cage experiments. This paper reports the results collected since 1972 and also some frequency figures from 1952 onwards.

\section{Materials and methods}

\section{Open field trials}

Over the period from 1972-1982 a total of 35 field trials were carried out on spring and winter turnip rape. From 1972 to 1973 the field plot size was $25 \times 25 \mathrm{~m}$. This large size was designed to minimize the effect of beetles migrating from plot to plot. During the next three years the plots were made even larger $(50 \times 50 \mathrm{~m})$ and the replicates were located several kilometres apart. In 1977 a randomized block design was adopted with five replicates and a plot size of $4 \times 25 \mathrm{~m}$.

Between 1972 and 1975 winter turnip rape, cv. Gruber, spring turnip rape, cv. Torpe and spring swede rape, cv. Oro were grown in the trials. From 1976 to 1977 spring turnip rape, cv. Torch and winter turnip rape, cv. Gruber were planted and from 1978 onwards only spring turnip rape, $\mathrm{cv}$. Torch was grown. The seeding rates were $24 \mathrm{~kg} / \mathrm{ha}$ for winter turnip rape, $10 \mathrm{~kg} / \mathrm{ha}$ for spring turnip rape and 12 $\mathrm{kg} / \mathrm{ha}$ for spring swede rape. Recommended fertilizer rates, $100 \mathrm{~kg} \mathrm{~N} / \mathrm{ha}$, were applied. Tok E 25, nitrofen, was applied as a herbicide in most of the trials. The insecticide used in the experiments was fenitrothion in 1972-75 and permethrin in 1976-82. The treated plots were sprayed at the early bud stage and again just before flowering.

\section{Pest incidence}

Sampling was started when the first blossom beetles were migrating to the rape plants. At each sampling date, every third day on average, the growth stage of the rape plants was recorded as well.

The number of beetles was estimated in the field trials by two different methods. The number of beetles per 10 plants was counted in each of the blocks every third day. The first plants of the sample were selected at random from the rows after which every third was taken into the count. The beetles were counted on both sides of the yield block. In addition, a netted sample was always taken from the same block. The beetles were netted on warm, dry days between 10.30 and 15.30 with one sample consisting of 25 sweeps.

The number of eggs and larvae in the stands was counted on inflorescence samples taken twice a week, starting from the flower bud stage. In addition, soil samples were taken using an auger and the number of pupae in the samples was counted.

\section{Insect damage}

Plant samples for determining the number of damaged pods were taken at the stage when flowering was completed but when the plants were still green. At this stage it was still possible to count the number of blind stalks fairly accurately. Later, some of the blind stalks would have been lost and it would also have been difficult to differentiate between injuries caused by the blossom beetle and those arising from physiological pod abortion or other such causes. However, as a high proportion of the primordial flower buds at the tip of each raceme had set fruit, a large degree of error was possible in estimating injuries in the tips of the shoots. Also the total number of healthy pods was counted to give a more reliable picture of the amount of damage. "Tipdrop" damage caused by larvae was recorded in those rare cases where it occurred.

The following parameters were measured on the plant samples of $25 /$ block: plant height, number of branches, number of pods on the main raceme and branches, number of seeds in the pods and thousand seed weight. The first plant was selected at random from the rows and every third plant after that.

\section{Cage experiments}

The cage experiments were carried out during the summer of 1973 . The cages used in the 


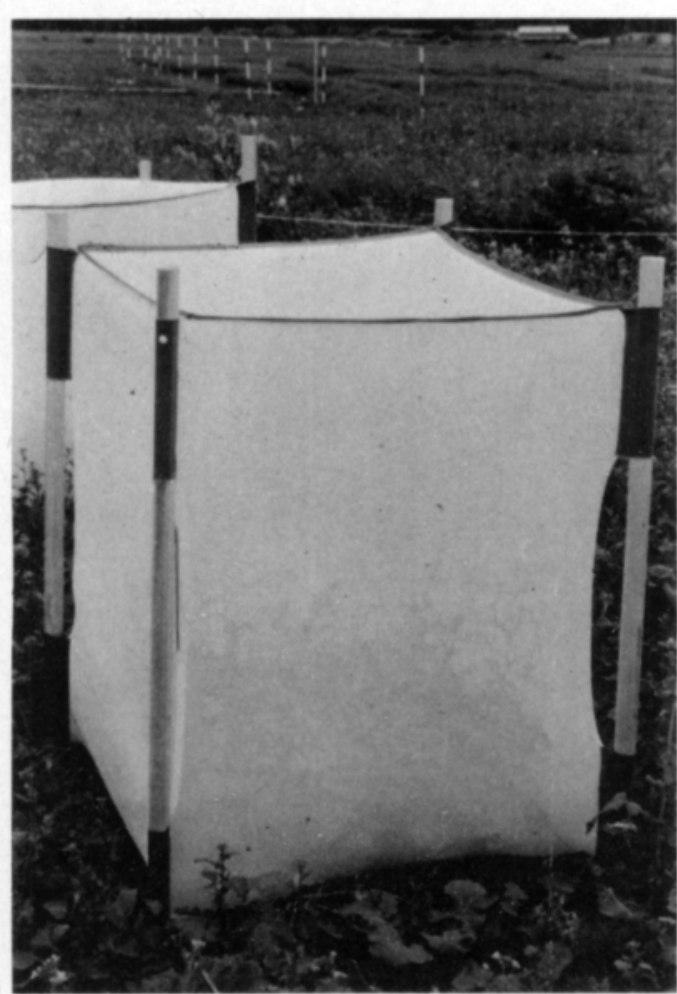

Fig. 1. The cages in cage experiments were covered with fibre netting.

experiments consisted of wooden frames covered with fibre netting of a mesh size small enough to prevent the passage of blossom beetles (Fig. 1). The basal area of the cages was $0.6 \mathrm{~m}^{2}$.

The cages were set out in the spring rape field after seedling emergence. The experimental units consisted of 5,15 and 25 beetles/plant, introduced at three different dates, and a control. The beetles were kept in the cages as follows: the first treatment from the seedling stage to the flowering stage, the second treatment from the flowering stage to maturity and the third treatment from the seedling stage to maturity. The experiments were carried out with four replicates making a total of 40 experimental units. The control cages were treated with fenitrothion. The first treatment was terminated by applying fenitrothion before the start of flowering. The beetles were collected from a neighbouring ra- peseed field the day before being placed in the cages.

The parameters measured in the cage experiments were yield/cage, number of branches, total number of pods, number of pods on the main raceme and branches and thousand seed weight.

\section{Results and discussion}

\section{The coincidence between rape plants and the blossom beetle}

On average, the first blossom beetles were observed on winter turnip rape from the first week of May onwards. When the spring was early, as for instance in 1974, the first blossom beetles could already be observed on the plants by the end of April. These beetles had obviously overwintered on the crop. The actual migration of the beetles to the crop did not begin until maximum daily temperatures had exceeded $+15^{\circ} \mathrm{C}$ for several days in succession (Fig 2). In 1982 the first beetles only started to appear on plant stands, mainly $T a$ raxacum officinale, during the latter half of May. The migration and swarming of the beetles thus followed the same temperature development in our study as in other studies (Nolte 1959, Free \& Williams 1979 b).

After overwintering the beetles can migrate directly onto winter turnip rape. Spring oil plants, however, do not serve as food and reproduction sites until early June (Fig 3). Thus, for the first two or three weeks, the beetles need other food plants (Fig 4). During the 1970 's when both winter and spring rapes were grown within the same area, the beetles first migrated to winter turnip rape in spring, then to spring turnip rape and finally to spring swede rape (Fig 5).

The maximum population densities were observed on winter rape just before or at the beginning of flowering of the main raceme, ie. in the middle of May (Fig 2). The peak densities on spring rape were observed during the same growth stage, which occurred one month 


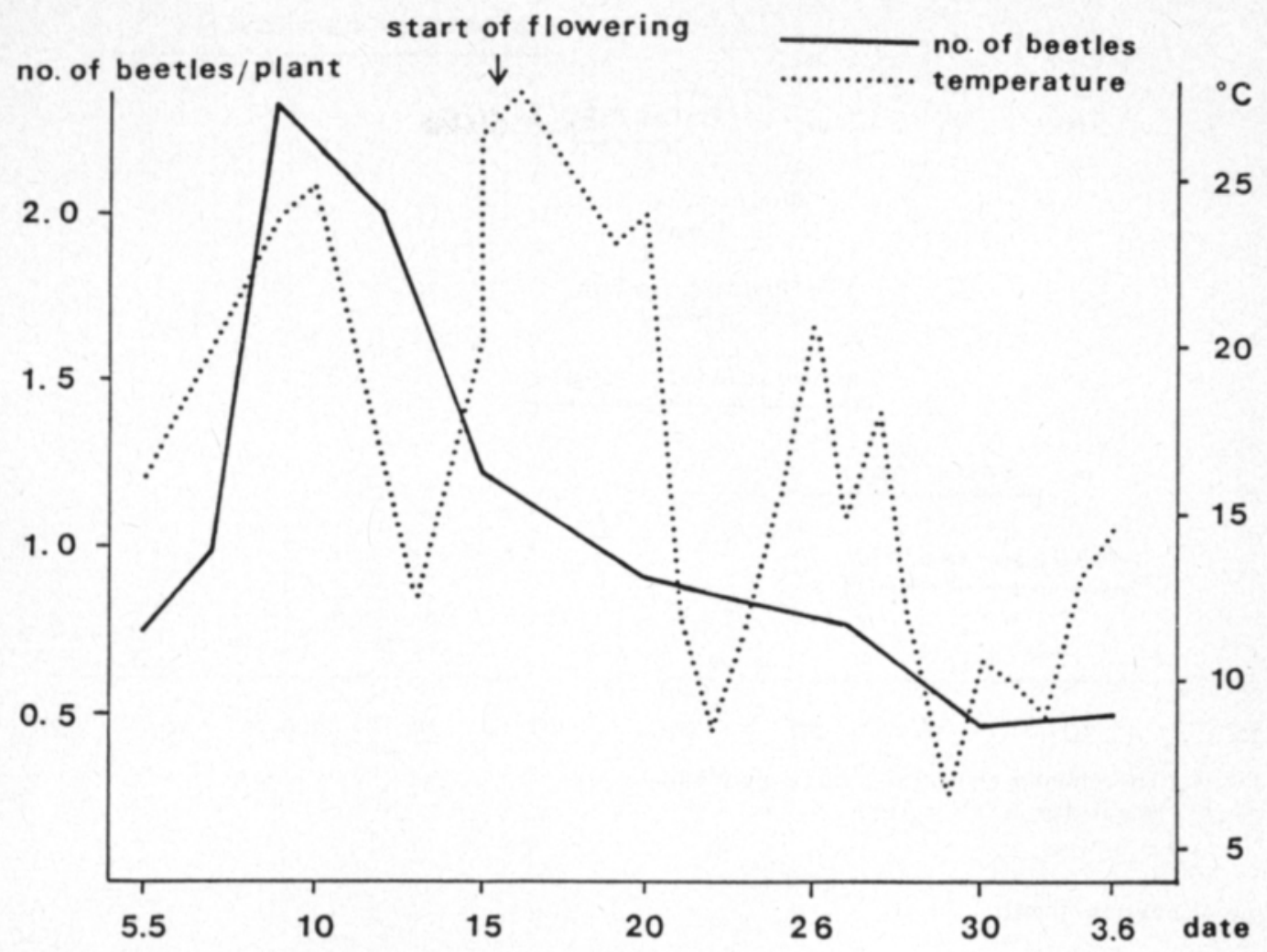

Fig. 2. The frequency of blossom beetles in the winter rape stand and maximum daily temperatures in 1975.

no. of beetles/plant

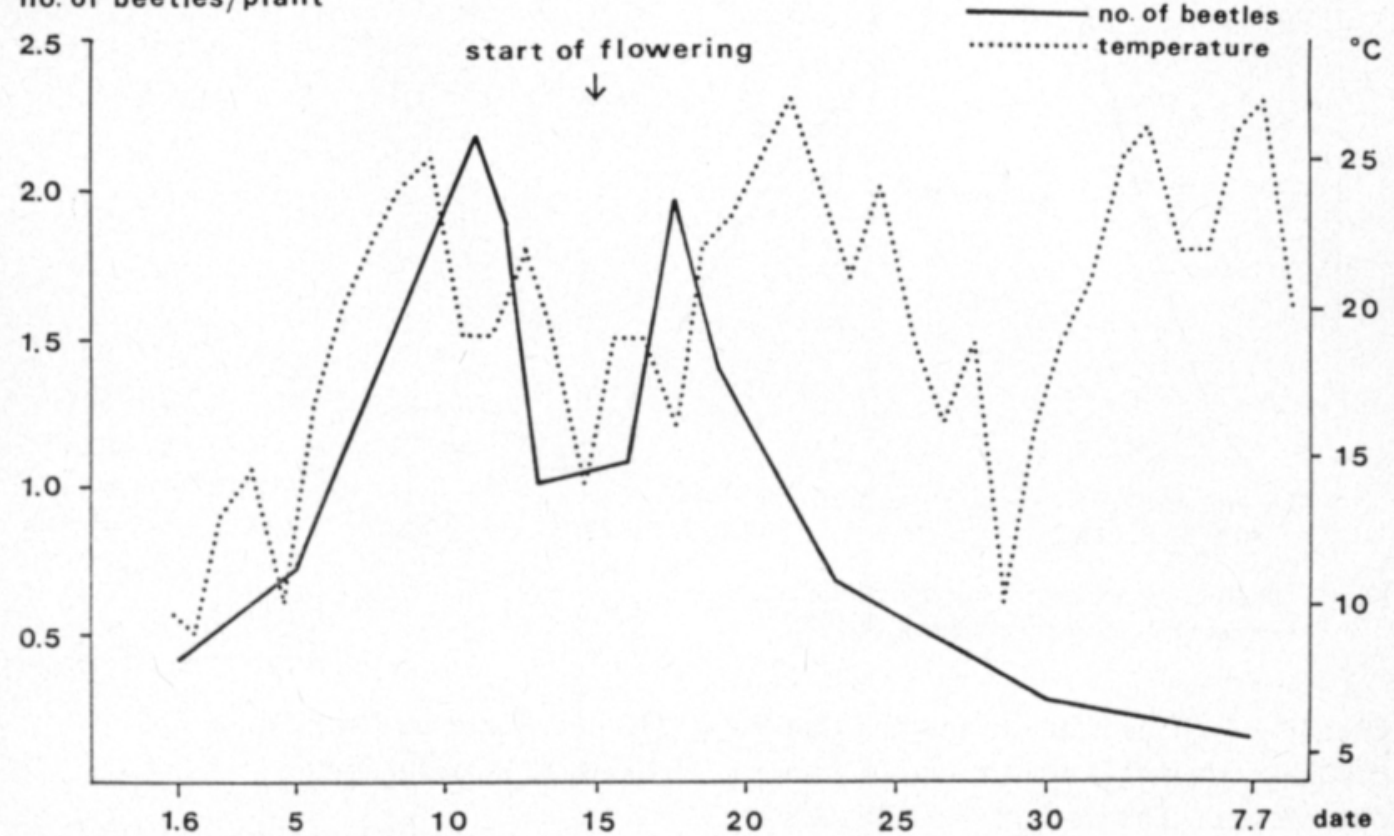

Fig. 3. The frequency of blossom beetles in a spring rape stand and maximum daily temperatures in 1975 . 


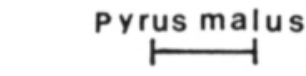

Prunus cerasus

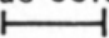

Prunus padus

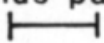

Taraxacum officinale

Salix sp.

Tussilago farfara

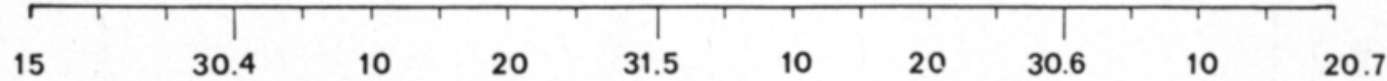

Fig. 4. The flowering time of the food plants of blossom beetles in early summer.

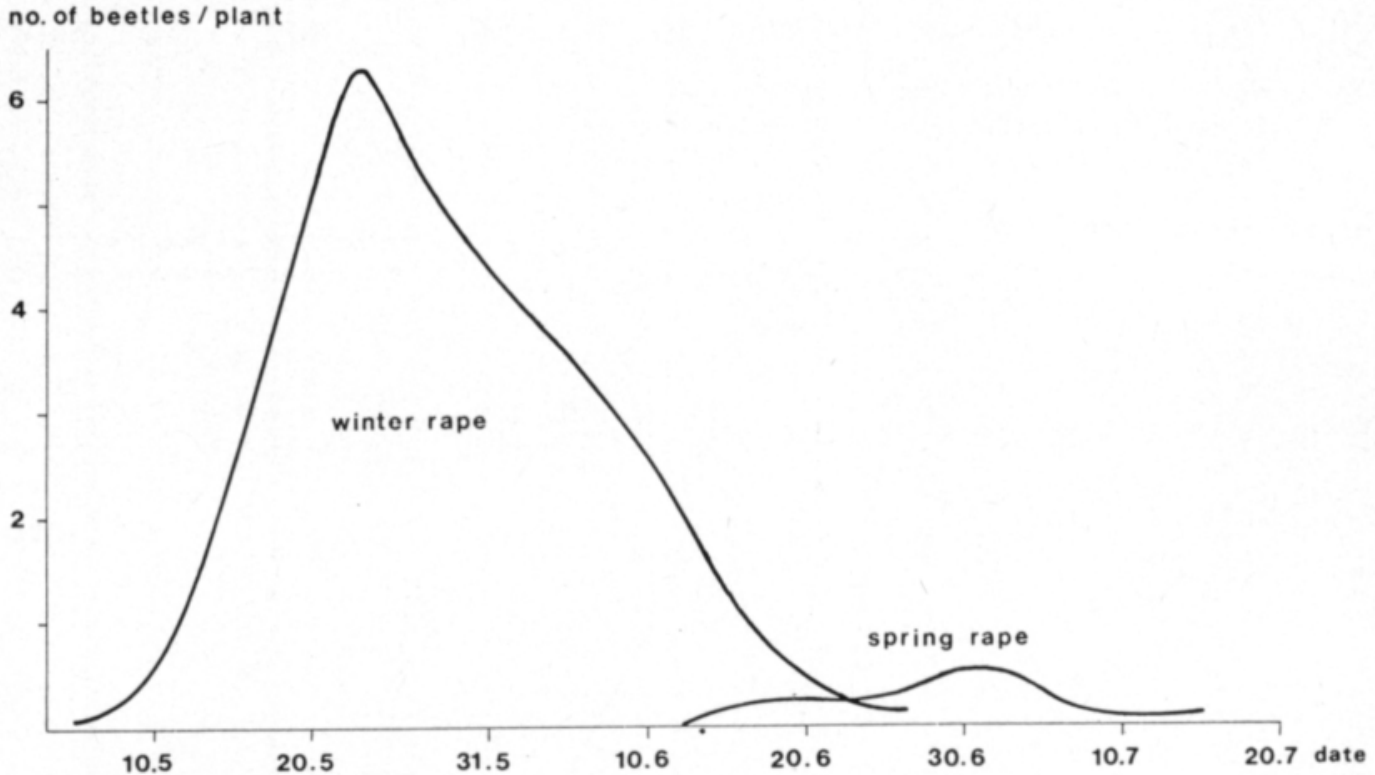

Fig. 5. Blossom beetle numbers observed on winter and spring rapes during the summer of 1977.

later (Fig 3). This is due to the fact that the beetles lay their eggs on rape buds but not on open flowers. The work of WiLliams \& FrEE (1978) among others confirms this observation.
The abundance and population growth of blossom beetles

Blossom beetles feed on the pollen of many different plant species (PRÜFFER 1958), but in 
Finland they reproduce only on cultivated crucifers and a number of wild brassicas (SAALAS 1943). In Finland most wild cruciferous plants flower relatively late. As a result the beetle population living on them is rather sparse, even though the blossom beetle presumably occurs throughout the country (VAPPULA 1962). The population growth and mass reproduction of the beetle are dependent on cultivated crucifers. Reproduction on winter rape is close to the optimum, while on spring oil crops it is normally lower.

Following the gradual phasing out of the cultivation of winter turnip rape and the slow

no. of beetles / plant

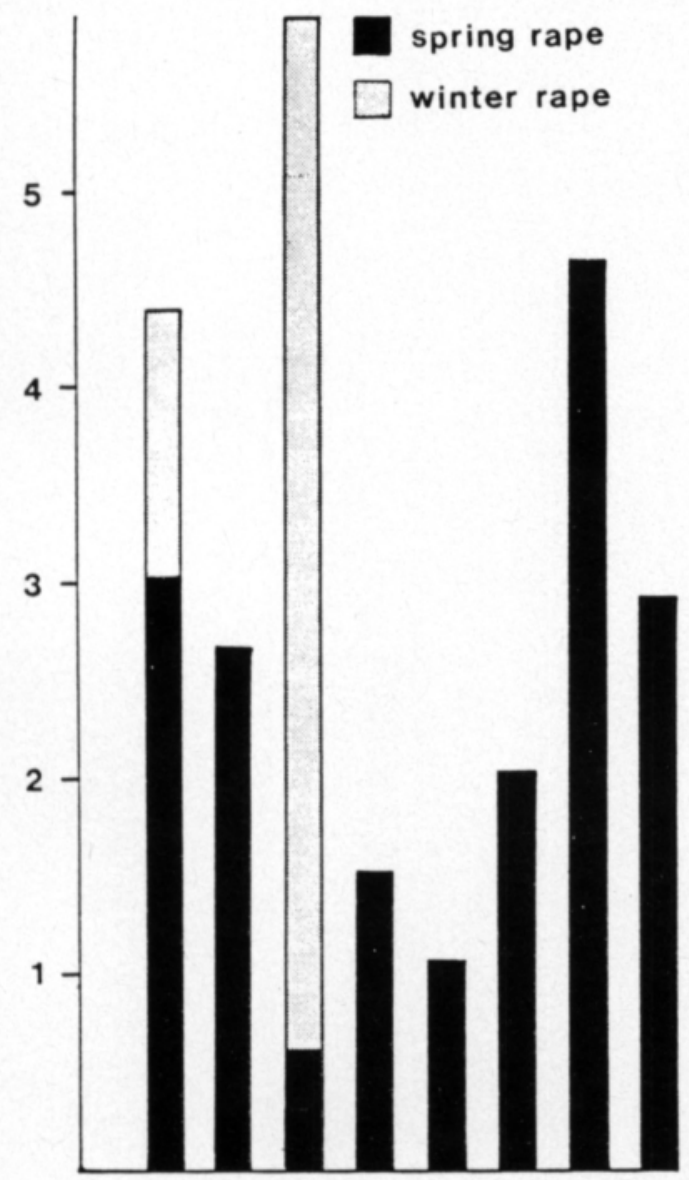

$\begin{array}{llllllll}1975 & 76 & 77 & 78 & 79 & 80 & 81 & 82\end{array}$

Fig. 6. Changes in the mean annual number of blossom beetles in winter and spring rapes in 1975-82. introduction of spring rapes, the mean annual number of beetles decreased right up till 1977 (Fig 6). Thereafter the steadily increasing field area of spring rapes did not need to be sprayed for many years. It was not until 1981, by which time the cultivation of these crops had reached considerable proportions that the beetles started to cause losses in several regions.

The reduction in size of the beetle population associated with the change in oil crop species can be partly explained by the fact that the reproduction of the beetles is more effective on winter rape than on spring rape. A considerable proportion of the beetles apparently die before their migration to their main regenerative source, i.e. spring oil plants. This explanation is further supported by the observation that when the spring is cool, the abundance of the beetles and their reproductive rate on spring rape appears to be higher because the migration of the beetles occurs later when spring rape serves better as a food source.

The variations in the numbers of larvae on winter and spring rape during 1977 are presented in Fig 7. Predators and parasites reduce the size of the larval population on the plants relatively little. Really significant population losses occur only when the larvae migrate into the soil to pupate (NILSSON 1985). In NiLSson's study the losses at this stage were estimated to rise to a maximum of $40 \%$ of the whole population. The reduction of population size during the winter has not been studied quantitatively, but is likely to be rather small.

The overall growth of the blossom beetle population depends mainly upon the availability of the regenerative host and is otherwise fairly constant. Apparently there is no weak point at any individual development stage, for example a specific parasite or disease, which in epidemic proportions could wipe out the population. The blossom beetle is thus a permanent pest possessing a stong reproductive capacity. This was clearly seen in the steady 


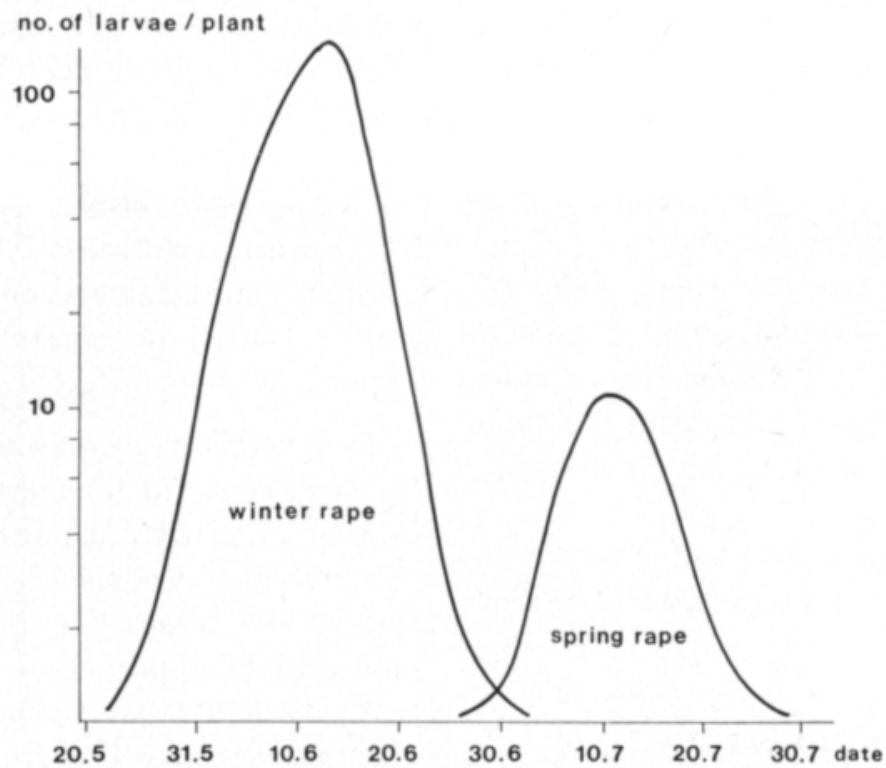

Fig. 7. The number of larvae/plant in winter and spring rape during the summer of 1977 .

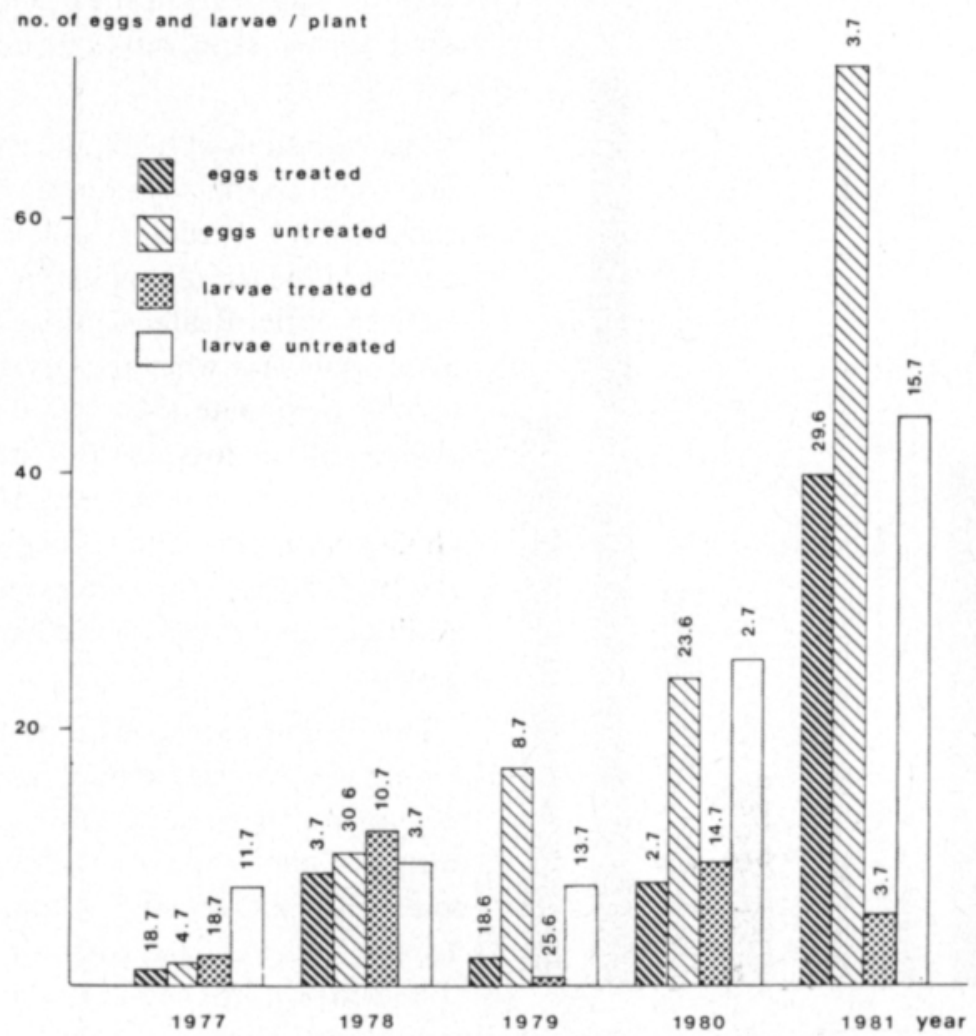

Fig. 8. Yearly variations in the number of larval progeny of blossom beetles and the effect of control measures in $1977-81$. 


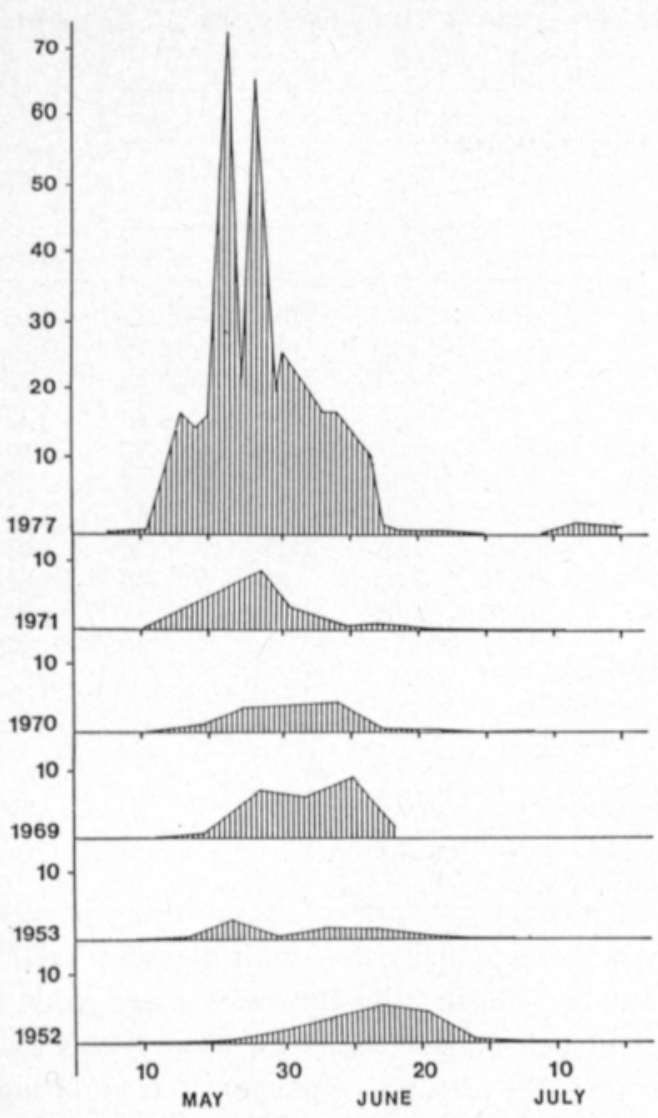

Fig. 9. Blossom beetle numbers in the netted samples collected from winter rape in 1952 - 77 . population growth after 1977 . The changes in the number of adult beetles (Fig 6) and the gradual increase in the number of progeny on the plant stands after 1977 (Fig 8) serve as examples of this.

The netted sample figures over a long period are presented in Figs 9 and 10 to depict the abundance of blossom beetles. Quite apart from annual variations in population abundance, one can observe that the time of peak occurrence varies over the years by almost a month. It would seem that during the twentyfive years from 1952 to 1977 , as winter rape displaced wild crucifers as the main food plant of blossom beetles, the population peak gradually shifted almost three weeks earlier.

These observations clearly show that the blossom beetle has been able to adapt itself to new plant species rather well. In the long

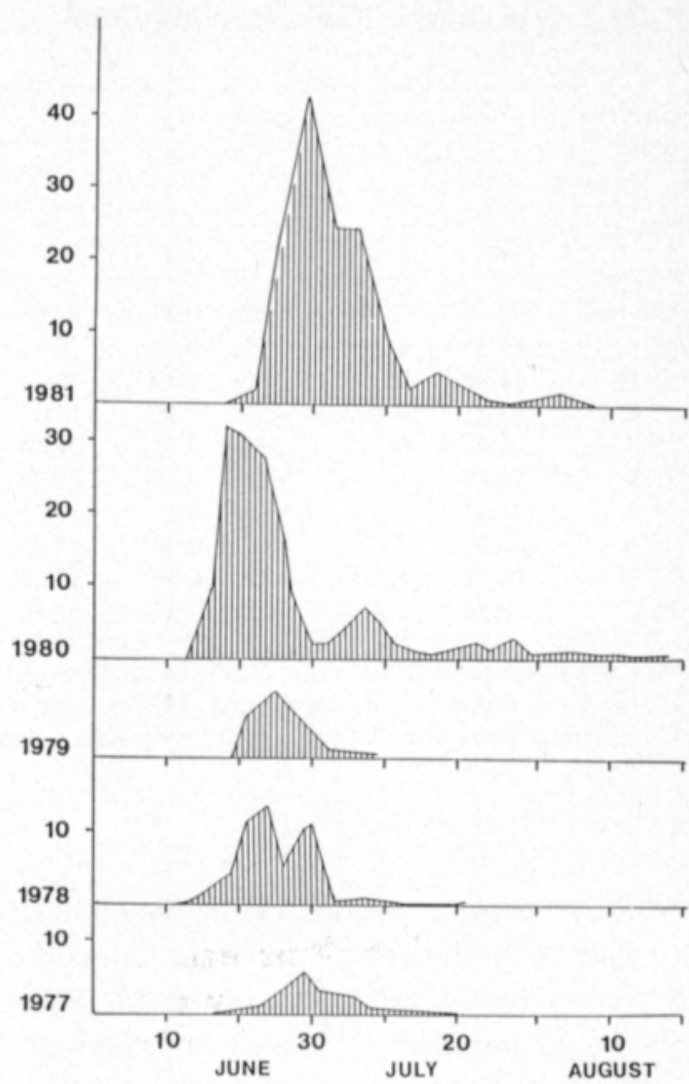

Fig. 10. Blossom beetle numbers in the netted samples collected from spring rape in $1977-81$.

run it remains to be seen whether the blossom beetle will be able to change its reproduction cycle to exploit spring oil plants more effectively. On the other hand, the seed weevil (Ceutorhynchus assimilis Payk.), previously an abundant pest on winter rape, has disappeared almost completely.

\section{The effect on yield}

\section{The cage experiments}

When the blossom beetles were kept on the plants for about one week at the bud stage, which corresponds approximately to field conditions, they did not have enough time to cause any significant decrease in yield (Table 1). However, all the beetle levels used reduced the number of siliquas on the main racemes, 
Table 1. The effect of blossom beetles on yield and yield components of spring turnip rape in cage experiments in 1973.

\begin{tabular}{|c|c|c|c|c|c|c|c|c|c|c|c|c|}
\hline \multirow{3}{*}{$\begin{array}{l}\text { Beetles/ } \\
\text { plant }\end{array}$} & \multirow{2}{*}{\multicolumn{2}{|c|}{$\begin{array}{c}\text { Yield/cage } \\
\mathrm{g}\end{array}$}} & \multirow{2}{*}{\multicolumn{2}{|c|}{$\begin{array}{l}\text { No. of } \\
\text { branches }\end{array}$}} & \multicolumn{6}{|c|}{ No. of healthy pods } & \multirow{2}{*}{\multicolumn{2}{|c|}{$\begin{array}{c}1000 \\
\text { seed weight } \\
\mathrm{g}\end{array}$}} \\
\hline & & & & & \multicolumn{2}{|c|}{$\begin{array}{l}\text { Terminal } \\
\text { raceme }\end{array}$} & \multicolumn{2}{|c|}{ Branches } & \multicolumn{2}{|c|}{ Total no. } & & \\
\hline & $\overline{\mathrm{x}}$ & $s_{\overline{\mathbf{x}}}$ & $\overline{\mathrm{x}}$ & $s_{\bar{x}}$ & $\overline{\mathrm{x}}$ & $\mathbf{s}_{\overline{\mathbf{x}}}$ & $\bar{x}$ & $s_{\bar{x}}$ & $\overline{\mathrm{x}}$ & $S_{\bar{x}}$ & $\bar{x}$ & $\mathbf{S}_{\overline{\mathbf{x}}}$ \\
\hline Control & 100.10 & 5.31 & 6.82 & 0.27 & 37.05 & 1.19 & 68.68 & 1.83 & 105.72 & 2.33 & 3.02 & 0.01 \\
\hline $5 \mathrm{~A}$ & 83.95 & 6.31 & 7.67 & 0.25 & 30.30 & 1.56 & 71.30 & 5.30 & 101.60 & 4.23 & 3.22 & 0.03 \\
\hline $5 \mathrm{~B}$ & 70.98 & 10.99 & 9.02 & 0.19 & 26.45 & 1.55 & 59.00 & 12.81 & 85.45 & 12.53 & 3.20 & 0.08 \\
\hline $5 \mathrm{C}$ & 53.25 & 4.89 & 8.48 & 0.90 & 15.07 & 1.93 & 35.25 & 5.46 & 50.32 & 6.10 & 3.23 & 0.08 \\
\hline $15 \mathrm{~A}$ & 104.86 & 9.11 & 7.82 & 0.63 & 25.30 & 1.21 & 79.97 & 7.56 & 105.27 & 6.72 & 3.04 & 0.09 \\
\hline $15 \mathrm{~B}$ & 60.50 & 8.80 & 7.35 & 0.35 & 24.58 & 2.63 & 29.38 & 3.69 & 57.05 & 6.14 & 3.08 & 0.03 \\
\hline $15 \mathrm{C}$ & 24.47 & 3.24 & 9.00 & 0.32 & 11.20 & 1.75 & 29.47 & 3.41 & 40.68 & 3.47 & 3.13 & 0.13 \\
\hline $25 \mathrm{~A}$ & 108.57 & 7.62 & 8.85 & 0.40 & 23.22 & 1.08 & 105.02 & 14.04 & 128.25 & 14.98 & 3.03 & 0.02 \\
\hline $25 \mathrm{~B}$ & 28.12 & 6.67 & 8.88 & 0.34 & 17.80 & 2.47 & 25.10 & 2.76 & 42.90 & 5.05 & 3.06 & 0.10 \\
\hline $25 \mathrm{C}$ & 12.38 & 2.41 & 9.80 & 0.46 & 3.80 & 0.85 & 87.32 & 11.45 & 91.13 & 11.34 & 2.78 & 0.02 \\
\hline
\end{tabular}

$A=$ Beetles present in the cages from the seedling to the flowering stage

$\mathbf{B}=$ Beetles present in the cages from the flowering stage to maturity

$\mathrm{C}=$ Beetles present in the cages from the seedling stage to maturity

while at the same time increasing the number of siliquas on the axillary racemes. This compensation explains the increase in yields when the larger numbers of beetles were present. The lowest beetle level used in the cage experiments may also occur under natural field conditions, but the two highest levels would be abnormally high.

In the other treatments the blossom beetles and their offspring remained on the plants either from the start of the flowering stage or throughout the whole growing season starting from the bud stage. With such long periods of exposure, even the lowest number of beetles introduced caused considerable damage. The presence of blossom beetles throughout the flowering period was sufficient to cause considerable yield loss. The flowering period lasts rather long, and part of the yield loss was caused by the larvae. During this stage the plants were no longer able to compensate for the damage by means of extra growth. Although the plants still formed new shoots, new siliquas failed to develop on them. This situation does not, however, correspond to field conditions, as blossom beetle densities are highest at the beginning of flowering and decrease rather quickly thereafter.
Contrary to former suppositions it was clearly seen that even small blossom beetle numbers during the flowering stage caused yield decreases. According to previous accounts, the presence of blossom beetles during the flowering stage should not cause any losses in yield (Williams \& Free 1978). Probably the growing larvae rather effectively curtailed the flowering of the plant by destroying not only flowers of the upper floral axis, but also by attacking the growing apex of both the main stem and its branches. In addition, it is obvious that the larvae, especially in great numbers, also strain the plants much and decrease their ability to compensate.

Although it is mere speculation to draw direct conclusions concerning the results of the cage experiments, they did at least give new information on one important aspect. A stand in good condition can probably carry rather high numbers of beetles for a few days before flowering without any yield losses resulting, provided the beetles are destroyed after that. The plants may compensate for flower buds injured or destroyed by blossom beetles by producing new racemes, extra buds on existing racemes, or by increasing the size of seeds in the remaining pods as WINFIELD (1961) has 
also noticed. However, the plant's ability to compensate decreases quickly as the flowering advances towards the side stems.

When great numbers of blossom beetles occur in the field, the onset of flowering is delayed and the colour of the flowering field is much lighter than in healthy vegetation. Serious blossom beetle damage can thus be seen by the colour of the vegetation from a distance.

\section{Open field trials}

Studies were carried out from 1976 to 1982 to clarify how naturally varying populations of blossom beetles affected rape yields under field conditions. An attempt was made to keep the control plots free of beetles with insecticides, but due to the mobility of the insects it was practically impossible to eliminate them entirely. Thus slight injuries were observed also in the control plots. Likewise, the insecticides caused slight phytotoxic symptoms on rape. Insecticide applications nonetheless gave effective control of blossom beetle peaks during the bud stage. Only in 1978 was the degree of control poor, owing to bad weather.

Blossom beetle numbers over the trial period were very low, only during the 1976 and 1981 seasons did they exceed 2 beetles/plant. In 1981 the development of the rape stands was hampered by drought as well as by large number of beetles, and yields fell to a very low level. The results of the trials are given in Table 2 .

Even though the effects of the blossom beetle populations on yield formation in spring rape varied considerably from year to year, it is quite evident that numbers of beetles even lower than 2 beetles/plant can result in yield losses. Actual yield losses in the trials ranged from $0-34 \%$, with the largest numbers of insects, as expected, causing the highest levels of damage. In 1977, when few beetles occurred, the untreated stands produced higher yields than the stands kept free of beetles. The implication here is that within certain limits, a blossom beetle population will not necessa- rily result in a yield loss; it may even increase the yield. Slight injuries during the early stages of yield formation may stimulate the plant to compensate by means of additional growth. On the other hand, when beetle numbers are low, the effects of insecticides may be negative due to their phytotoxicity.

The yield losses caused by blossom beetles are related mainly to a reduction in the number of healthy pods producing seed, both in the main raceme and in side branches. Nonetheless, this loss was partly compensated for by the fact that the remaining pods carried a larger number of heavier seeds. The injuries inflicted by the beetles also stimulated the production of side branches, but for the most part these new branches did not bear productive pods. The beetles had no effect upon the height of the rape stands (Table 2).

The impact of blossom beetle populations upon yield formation in rape depends not only upon the degree and time of injury, but very decisively upon the prevailing growing conditions. Provided the conditions are otherwise favourable, even extensive injury to the main stem will not necessarily reduce yields, as a stand in good condition will be able to compensate for the injury by means of side branches. This compensative ability does fall off, though, as flowering progresses. The most severe losses are incurred in a situation where the plants are suffering from drought and lack of nitrogen. Under such conditions even small numbers of beetles can cause yield losses. It would appear that the larvae contribute to these losses to a greater extent than previously thought, which again becomes manifest eg. during a drought. This idea is supported by the results of the cage experiments, in which a large population of beetles at the early bud stage did not cause yield losses, provided the plants were kept free of the beetles and their larvae thereafter.

\section{Chemical control and threshold levels}

At the present time, the only realistic way of controlling blossom beetles is by the use of 


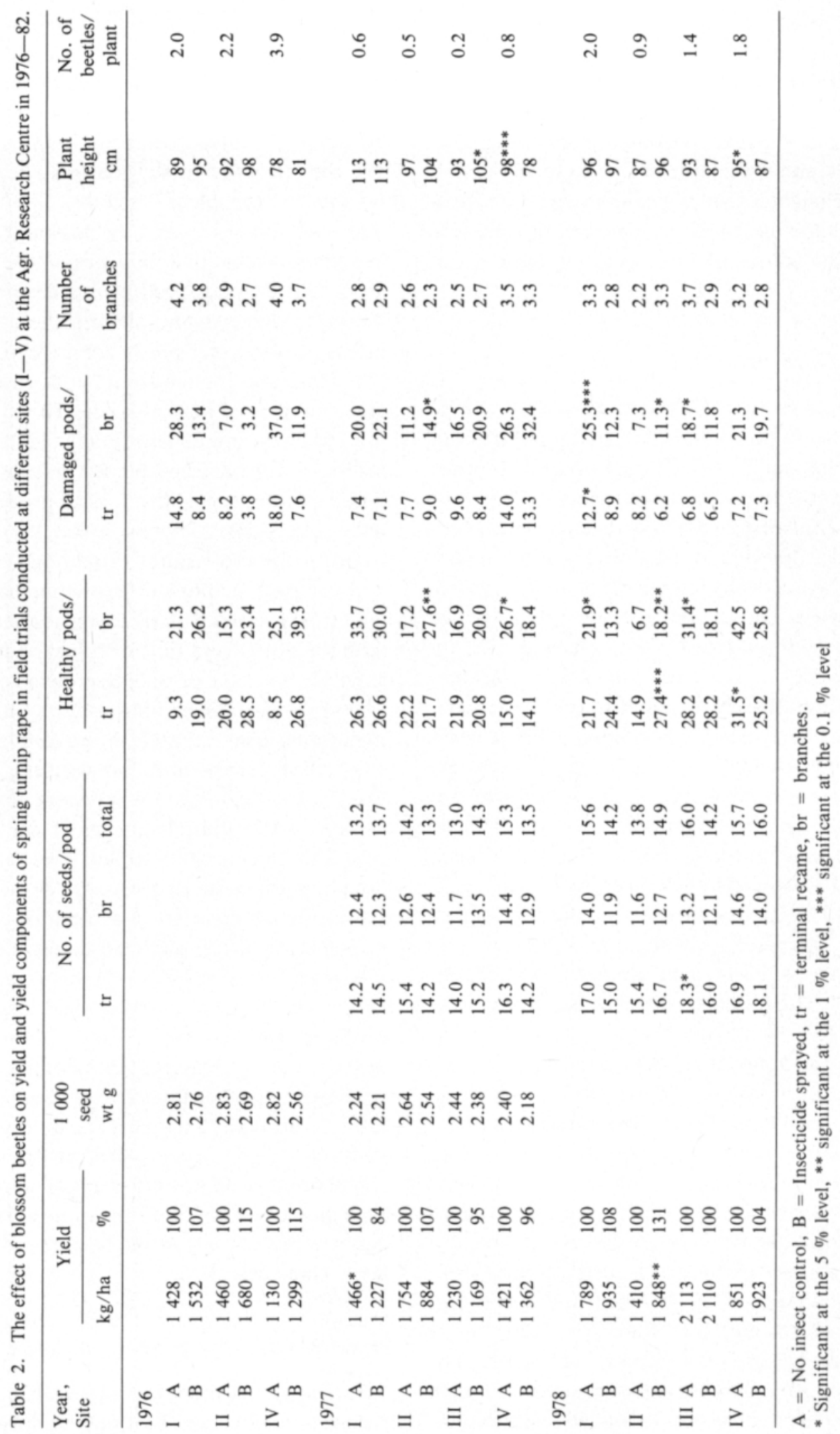




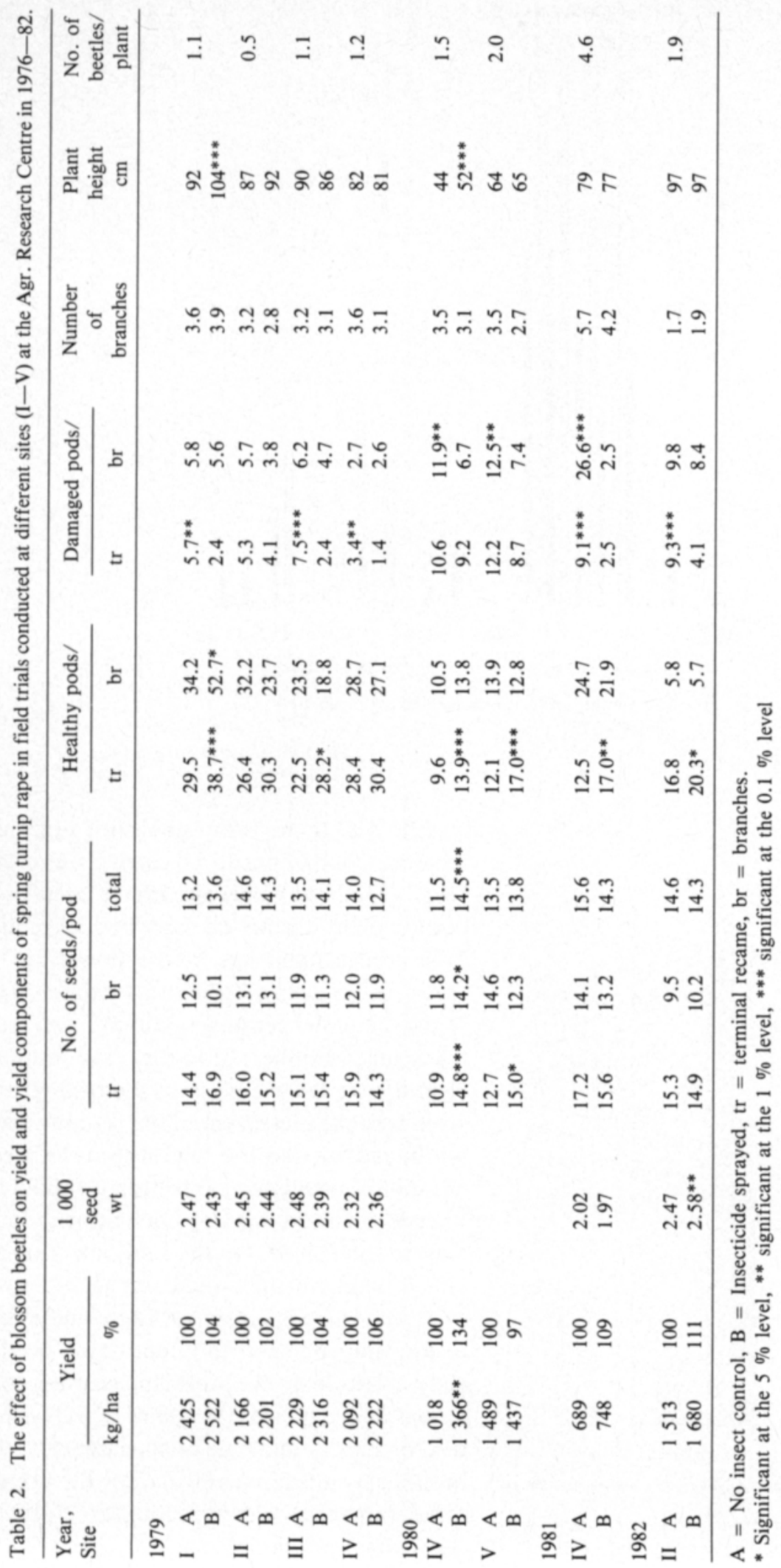




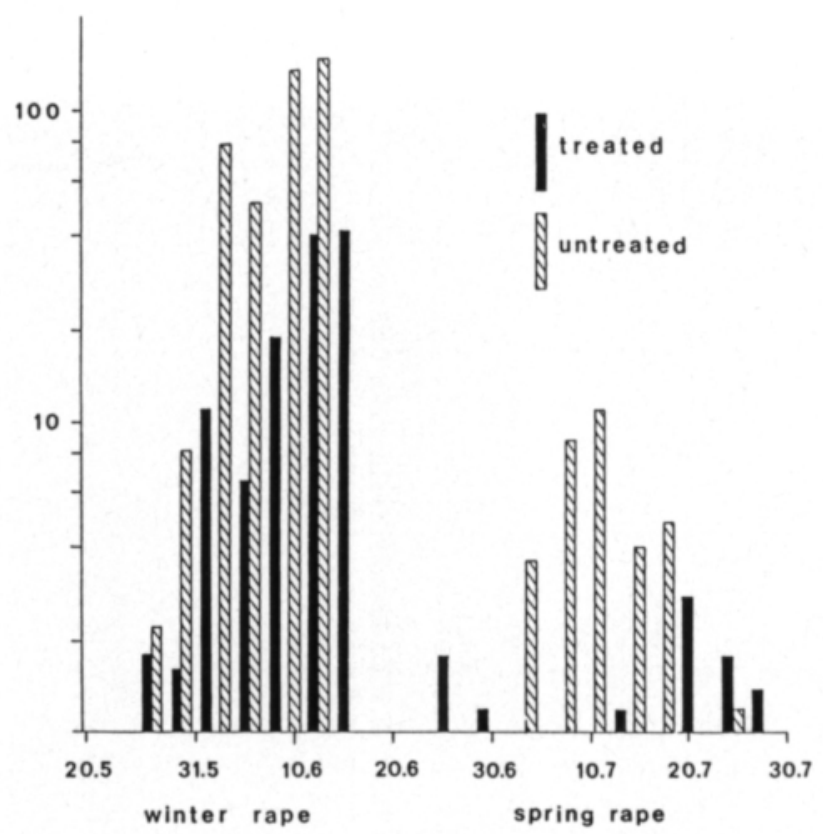

Fig. 11. The number of larvae on treated and untreated plants in 1977.

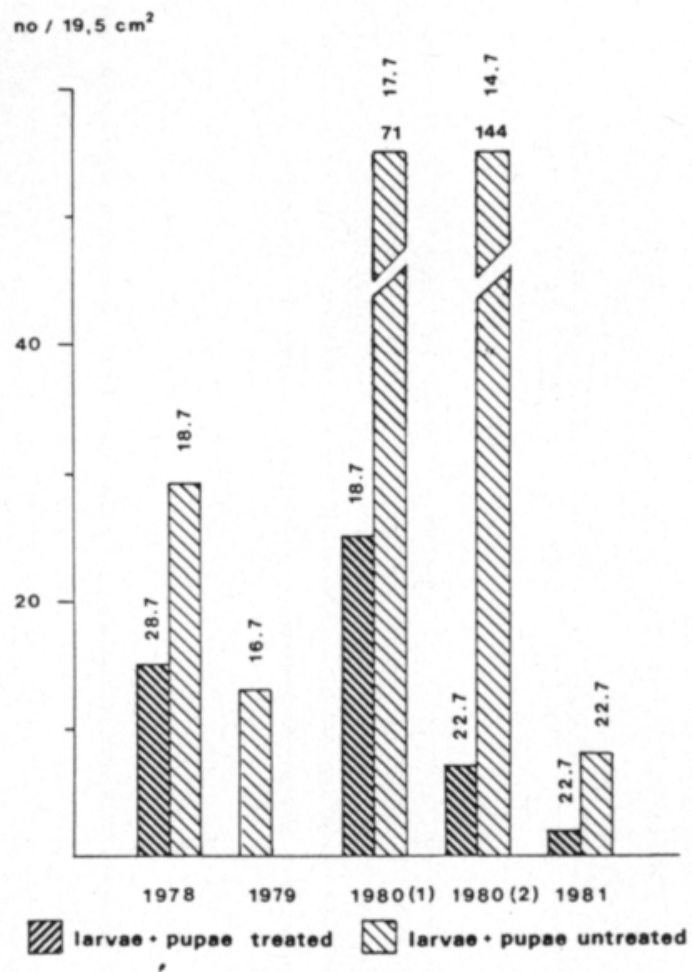

Fig. 12. The number of larvae and pupae in soil samples in treated and untreated plots in 1978-81. insecticides. In areas of established rape cultivation, control has to be carried out every year. Threshold values used have been $1-2$ beetles/plant during the early bud stage and $2-3$ beetles/plant just before flowering.

As the results of field trials demonstrate (Table 2), under certain conditions even relatively small numbers of beetles may result in yield losses. On the basis of the trial results given here the present threshold certainly cannot be regarded as too low; within the areas of established oilseed cultivation it should be 1 beetle/plant. In this way population growth may be forestalled. On the subject of thresholds for control one should emphasize, however, that there is no simple cause and effect relationship between the number of beetles and oilseed yield. The prevailing growing conditions and vigour of the stand, as well as the level of activity and time of appearance of the beetles play a decisive role in how the beetles affect rapeseed yield formation as WINFIELD (1961) has also noticed. 
The larvae should receive more attention than hitherto, since they obviously contribute greatly to the stress undergone by the plants, and reduce the plants' compensative ability. Destruction of the larvae will also control effectively the population growth of future generations. An application of insecticide given just before flowering has a clear effect upon larval progenies found on the plants (Fig. 11) and thus upon the numbers of prepupal larvae burrowing into the soil and of pupae (Fig. 12).

Since the insecticides used show little persistence (Tulisalo 1983), the application should be made at least twice; the first at the early bud stage and the second just before the first flowers open, if control is to be effective. If the beetles are present in small numbers, a single application delayed as far as possible towards the beginning of flowering should be adequate.

According to Free and Williams (1979 a), merely spraying the margins of a rapeseed field may, especially on an extensive area, effectively reduce pest populations. The application should then be made when the beetles are migrating, at which time most of them are to be found on the margins of cultivation. The insecticide is best applied simultaneously on nearby cultivations as well, since the beetles are exceedingly mobile.

In the future, the optimal control strategy will no doubt consist of a highly comprehensive and efficient programme on a local or regional basis in two to three year sequencies during which the beetles should be controlled even when their number is lower than the threshold level. During the intervening seasons control methods would, in general, only be taken if necessary. In this manner, blossom beetle populations could be regulated and their expansion held in check throughout an entire region of cultivation.

By manipulating the sowing date of rape, one can attain some degree of control over blossom beetle damage. A given region of cultivation always consists of different aged stands, and the beetles cause more severe damage on the early sowings. The lowest numbers are generally found on late sown stands, where control is rarely necessary.

\section{References}

Blazejevska, A. 1960. Studies on biology of Meligethes aeneus Fabr.. Stud. Soc. Sci. Torun., Torun (E) 5: $121-189$.

Burkhardt, F. \& Lengerken, H. von. 1920. Beiträge zur biologie des Rapsglanzkäfers (Meligethes aeneus Fabr.). Z. Angew. Ent. 6: 270-295.

FABer, F., Fisher, G. \& Kalt, B. 1920. Die Biologische Bedeutung des Rapsglanzkäfers für Raps, Rübsen und Senf. Beobachtungen und Versuche des Jahres 1919. Landw. Jb. 54: 681-701.

Free, J.B. \& Williams, I.H. 1978. A survey of the damage caused to crops of oilseed rape (Brassica napus L.) by insect pests in south-central England and their effect on seed yield. J. Agric. Sci. 90: 417-424.

-, Williams, I.H. 1979 a. The distribution of insect pests on crops of oil-seed rape (Brassica napus L.) and the damage they cause. J. Agric. Sci. 92: 139-149.

-, Williams, I.H. 1979 b. The infestation of crops of oil-seed rape (Brassica napus L.) by insect pests. J. Agric. Sci. 92: 203-218.

FrizsCHE, R. 1957. Beeinflussung der Populationsdichte verschiedener Meligethes-Arten von gleichen Wirtspflanzen durch Parasiten. Ber. 100-Jahrfeier Dtsch. Ent. Ges., Berlin. p. 141-145.

Galuus, 1866. Zur Naturgeschichte des Rapsglanzkäfers, Meligethes (Nitidula) aeneus F.. Annalen der Lantwirtschaft der königlichpreussischen Staaten, Wochenblatt 1866: 48-49, 56-58.

Gould, H.J. 1975. Surveys of pest incidence on oil-seed rape in south central England. Ann. Appl. Biol. 79: $19-26$.

HEEger, E. 1854. Beiträge zur Naturgeschichte der Insekten, 13. Forts.: Meligethes aeneus Fabr.. S. B. Akad. Wiss. Wien, math.-naturw. KL. 14: 278-281.

Maurer, H. \& Menche, A. 1940. Schadfrass von Rapsglanzkăferlarven an Raps und Rübsen. Z. Pfl.krankh. Pfl.schutz 50: 500-507.

McGregor, D.I. 1981. Pattern of flower and pod development in rapeseed. Can. J. Plant Sci. 61: 275-282.

Mendham, N.J. \& Scott, R.K. 1975. The limiting effect 
of plant size at inflorescence initiation on subsequent growth and yield of oilseed rape (Brassica napus L.). J. Agric. Sci. 84: 487-502.

NiLsson, C. 1985. Impact of ploughing on emergence of pollen beetle parasitoids after hibernation. Z. Angew. Ent. 100: 302-308.

Nolte, H-W. 1954. Käfer bedrohen den Raps. Über die Biologie, die Bedeutung und die Bekämpfung des Rapsglanzkäfers. Die neue Brehm-Bücherei 124.40 p. Wittenberg-Lutherstadt.

-, 1959, Untersuchungen zum Farbensehen des Rapsglanzkäfers (Meligethes aeneus F.). II Ergebnisse für die praxis des Schädlingswarndienstes. Z. Angew. Zool. 46: $11-33$.

Otsson, G. 1960. Some relations between number of seeds per pod, seed size and oil content and the effects of selection for these characters in Brassica and Sinapis. Hereditas 46: 27-70.

OsBorn, P. 1960. Observations on the natural enemies of Meligethes aeneus $(\mathrm{F}$.$) and M$. viridescens (F.). (Coleoptera: Nitidulidae). Parasitology 50: 91-110.

Pallut, W., Lócke, W. \& Legde, G. 1984. Effektive Bekämpfung tierischer Schaderreger im Winterraps. Nachr.bl. Pfl.schutz in der DDR 38: 117-120.

Pruffer, K. 1958. Feeding of Meligethes sp. in the flowers of different species of plants. Stud. Soc. Sci. Torun., Torun (E) 5: 121-189.

REUTER, E. 1898. Kertomus tuhohyönteisten ilmestymisestä Suomessa vuonna 1897. Maanvilj.hall. tiedonant. 23: $1-69$.

\section{SELOSTUS}

\section{Rapsikuoriaisten (Meligethes aeneus Fab.) vaikutus rypsin (Brassica campestris $\mathbf{L}$.) sadon muodostukseen}

\author{
Unto Tulisalo \\ Öljynpuristamo Oy, SF-00810 HELSINKI, Finland
}

\section{Tuomo Wuori}

\section{Ritokalliontie II C, SF-00330 HELSINKI, Finland}

Maatalouden tutkimuskeskuksessa Vantaalla selvitettiin vuosina 1972 -82 kenttäkokeissa sekä häkkikokeissa rapsikuoriaisten esiintymistä ja vaikutusta rypsin sadon muodostukseen. Kuoriaiset siirtyivăt syysrypsikasvustoihin toukokuussa, kun päivälämpötila kohosi $+15^{\circ}$ C:een, ja kevătrypsille ne siirtyivät $n$. 3 viikkoa myöhemmin. Populaatiohuippu oli sekă syys- ettă kevătrypsillă juuri ennen kukintaa. Syysrypsin, rapsikuoriaisten pää-
SAALAS, U. 1943. Maatalouden tuho- ja hyötyeläimet. Vanamon kirjoja. 497 p. Helsinki.

TAYo, T. O. \& MoRgan, D. G. 1975. Quantitative analysis of the growth, development and distribution of flowers and pods in oilseed rape (Brassica napus L.). J. Agric. Sci. 85: 103-110.

TulisAlo, U. 1983. Långtidsverkan av pyretroider vid bekämpning av rapsbagge. Växtskyddsnotiser 47: 91-96.

VAPPULA, N.A. 1962. Suomen viljelykasvien tuhoeläinlajisto. Ann. Agr. Fenn. 1, Sarja tuhoeläimet 5: 1-275.

Williams, I.H. \& Free, J.B. 1978. The feeding and mating behaviour of pollen beetles (Meligethes aeneus Fab.) and seed weevils (Ceutorhynchus assimilis Payk.) on oil-seed rape (Brassica napus L.) J. Agric. Sci. 91: 453-459.

—, \& FreE, J.B. 1979. Compensation of oil-seed rape (Brassica napus L.) plants after damage to their buds and pods. J. Agric. Sci. 92: 53-59.

WiNFIELD, A.L. 1961. Field observations on the control of blossom beetles (Meligethes aeneus F.) and cabbageseed weevils (Ceuthorhynchus assimilis Payk.) on mustard-seed crops in East Anglia. Ann. Appl. Biol. 49: 539-555.

WolfF, M. \& Krause, A. 1925. Beiträge zur Kenntnis der Biologie von Ölfruchtschädlingen, insbesondere über den Anteil der von Ceuthorrhynchus assimilis verursachten, fälschlich dem Meligethes aeneus zugeschriebenen Schäden. Arch. Natg. Abt. A, 91 no 4: 1-45.

Ms received December 19, 1986 asiallisen ravintokasvin, viljelyn supistuminen ja kevătrypsin yleistyminen vähensivăt 1970-luvulla kuoriaismääriä niin paljon, ettă vasta vuonna 1981 esiintyi uudestaan laajemmin torjuntatarvetta. Vaikuttaa siltă, ettă rapsikuoriaiset ovat vähitellen sopeutumassa kevătrypsin kasvurytmiin.

Häkkikokeissa kasvustossa pidettiin 5,15 tai 25 kuoriaista/kasvi a) taimivaiheesta kukintaan, b) kukinnasta 
tuleentumiseen ja c) taimivaiheesta tuleentumiseen saakka. Ensimmäisessä käsittelyssä kuoriaiset eivăt vaikuttaneet merkittăvästi satoon, sillă kasvit pystyivăt kompensoimaan vioitusta. Muissa käsittelyissả jo pienin kuoriaismaaără vähensi satoa. Toukilla oli oma osuutensa sadon alennukseen. Ilmeisesti hyväkuntoinen kasvusto sietăă melko korkeitakin kuoriaismäăriä muutamia päiviä ennen kukintaa, jos kuoriaiset tuhotaan sen jälkeen.

Kenttăkokeissa luontaisten kuoriaispopulaatioiden aiheuttamat satotappiot olivat $0-34 \%$. Vielă $2 \mathrm{kpl} / \mathrm{kasvi}$ pienemmät kuoriaismäärät alensivat selvästi satoa. Kuoriaisten vioittamat kasvit tuottivat verrannetta vähemmän lituja, mutta pyrkivăt kompensoimaan tătă lisaaămällă siemenmaaărăă ja -kokoa.

Suoritetut kokeet vahvistavat, että torjunnan kynnysarvoa, 1 kuoriainen/kasvi aikaisella nuppuasteella, on syytă noudattaa. Toisaalta kokeet osoittavat myös, ettă kynnysarvon suuruus riippuu olennaisesti kasvuolosuhteista. Todella tehokas torjunta edellyttää yleensä kahta torjuntakertaa. Tulevaisuudessa paras torjuntastrategia olisi ilmeisesti mahdollisimman tehokas alueellinen torjunta muutaman, ehkä $2-3$ vuoden jaksoina, jolloin kuoriaispopulaatiot eivăt paaäse kasvamaan liian suuriksi. 